\title{
Yeni Tanı Akut Myeloblastik Lösemide Femur Başı Avasküler Nekrozu Benzeri Görünüm*
}

\author{
Atakan TURGUTKAYA, İrfan YAVAŞOĞLU \\ Adnan Menderes Üniversitesi Tıp Fakültesi, Hematoloji Bilim Dalı, Aydın.
}

\section{ÖZET}

Avasküler nekroz kemiğin vasküler yapısına veya direkt olarak kemik ve kemik iliği yapılarına hasarlanma sonucu oluşan ve kemik ve kemik iliği hücrelerinin ölümüne yol açan; sonuç olarak kısa sürede eklem destruksiyonuna yol açan bir durumdur. Hematolojik veya hematolojik olmayan sebepleri mevcuttur. Özellikle hematolojik malignitelerden akut lenfoblastik lösemi gösterilse de geç dönemde özellikle tedavinin bir komplikasyonu olarak akut myeloblastik lösemide de gözlenebilmektedir. AML'li olguların femur başı avaskuler nekrozu ile prezente olması çok nadir bir durumdur ve septik artritten ayrımı zordur.

Anahtar Kelimeler: Femur başı. Nekroz. Lösemi.

Femoral Head Avascular Necrosis Like Appearence on the New Onset Acute Myeloblastic Leukemia

\begin{abstract}
Avascular necrosis is a process that occurs with the destruction of directly to the bone or bone marrow itself or to the vascular compartments and becomes the reason of joint destruction consequently in a short manner of time. It has hematological and non-hematological reasons. It has been postulated to accompany with acute lymphoblastic leukemia among hematological malignancies but also has been observed during late stages of acute myeloblastic leukemia especially as a complication of its treatment. The presentation with femoral head avascular necrosis on new onset AML is a rare situation and it can be challanging to discriminate it from septic arthritis.
\end{abstract}

Key Words: Femoral Head. Necrosis. Leukemia.

Avasküler nekroz (aseptik nekroz, atravmatik nekroz, iskemik nekroz) kemiğin vasküler yapısına veya direkt olarak kemik ve kemik iliği yapılarına hasarlanma sonucu oluşan ve bu hücrelerinin ölümüne yol açan; sonuç olarak kısa sürede eklem destruksiyonuna yol açan bir durumdur. Gözden kaçabilmesi nedeniyle gerçek prevelansı bilinmemektedir. Patofizyolojisi tartışmalı olsa da intraosseöz basınç artışı, sitotoksik hücresel faktörler, damar içi pıhtılaşma, venöz staz ve hiperviskosite sendromunun altta yatabileceği bildi-

Geliş Tarihi: 01.Haziran.2020

Kabul Tarihi: 11.Ağustos.2020

* 6. Hematolojik Onkoloji Kongresi'nde (Girne/Kıbrıs, 1921.09.2019) Olgu Sunumu bildirisi olarak sunulmuştur.

Dr. Atakan TURGUTKAYA

Adnan Menderes Üniversitesi Tıp Fakültesi,

Hematoloji Bilim Dalı,

Aytepe Mevki, Efeler,

Aydın.

Tel: 05464139752

E-posta: atakanturgutkaya@yahoo.com.tr

Yazarların ORCID ID Bilgisi:

Atakan TURGUTKAYA: 0000-0001-8428-4730

İrfan YAVAŞOĞLU: 0000-0003-1703-2175 rilmektedir ${ }^{1}$. Hematolojik hastalıklar, femur başı avaskuler nekrozu (FBAVN) tablosuna sebep olan hastalıkların bir grubunu oluşturmaktadır. Bunlara en sık örnek olarak orak hücreli anemi, hemofili, aplastik anemi, talasemi ve akut lenfoblastik lösemi (ALL) gösterilmektedir ${ }^{2}$. Literatürde de çoğunlukla hematolojik malignite olarak ön planda pediatrik ALL olguları yer almaktadır. Akut myeloblastik lösemi (AML) önde gelen nedenlerden birisi değildir ve bu olgularda FBAVN gelişimini kolaylaştıran nedenler arasında kemik iliği nakli ve uzun süreli steroid kullanımı mevcuttur $^{3}$. Burada kalça ve yaygın kemik ağrısı nedeniyle hekime başvuran ve kalça MR'ında FBAVN benzeri değişiklikleri olan, sonrasında AML tanısı alan bir olgu sunulmuştur.

\section{Olgu Sunumu}

Kırk sekiz yaşında erkek hasta, 10 gündür, özellikle sol kalça ekleminde olmak üzere tüm vücutta yaygın ağrı hissetmesi ve dış merkezde lökositoz ve bisitopeni saptanması üzerine polikliniğimize başvurdu. Özgeçmişinde bir hastalık öyküsü ve ilaç veya alkol kullanımı yoktu. Hemogram tetkikinde WBC: 45930/mkrL, Neu:22370/mkrL, Monosit:18600/mkrL, 
Hb:9,5 gr/dl, PLT: 17000/mkrL saptandı. Periferik yaymasında auer body içeren $\% 20$ oranında myeloblast görülen olgu AML tanısıyla hematoloji servisine yatırıldı. Yapılan kemik iliği aspirasyon/biyopsisinde de $\% 60$ oranında auer body içeren blastik hücre görüldü. Kemik iliğinden kromozom analizinde özellik olmayan hastada yeni nesil dizileme analizi ile bakılan NPM-1, FLT-3, CBFB-MYH11, CEBPA, PMLRAR $\alpha$, ASXL1 ve RUNX1-RUNX1T1 mutasyonlar1 negatif bulundu. Standart risk grubu olarak kabul edildi. Olgunun tedavisine başlandıktan hemen sonra, kalça ağrısı nedeniyle tetkik edildi. Eklem bölgesinde sıcaklık artışı ve şişlik yoktu. Kalça ve femura yönelik çekilen direkt grafisi normaldi. Çekilen kalça MR'ında sol femur başı torakanter majör düzeyinde yağlı kemik iliği değişiklikleri ve diğer kemik alanlarında yaygın sinyal değişiklikleri saptandı. Efüzyon, sinovial kalınlaşma gibi septik artrit bulguları görülmedi. Olgunun radyolojik görünümü FBAVN benzeri değişiklikler olarak yorumlandi. Ateşi mevcut olan olguda kalça bölgesinin septik artriti dışlanamadı. Eklem ponksiyonu ile eklem içi sıvıya yönelik direkt bak1-kültür incelemeleri koagülopati nedeniyle yap1lamadi. Ortopedi bölümü tarafından total kalça artroplastisi önerilse de mevcut durumu nedeniyle opere edilemedi ve parenteral antibiyoterapi ile izlendi. AML tedavisi ile remisyona giren olguda takip sürecinde kalça hareketleri veya yürüme fonksiyonunda bir azalma veya kalça ağrısında artış saptanmadı. Olgunun direkt grafi ve tanı anındaki MR görüntüsü Şekil-1 de gösterilmiştir. MR'da FBAVN benzeri görünüm okla belirtilmiştir. Remisyona girdikten sonra çekilen kontrol MR görüntüsü, tanı anındaki MR görüntüsü ile karşılaştırmalı olarak Şekil-2'de gösterilmiş olup FBAVN'nu destekleyen patolojik bulgu saptanmamıştır.

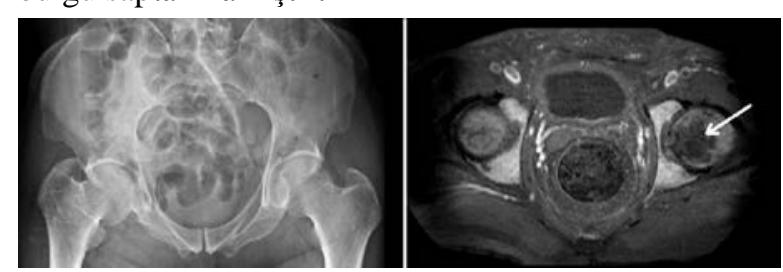

Şekil 1.

Hastanın direkt grafisi ve tanı anındaki MR görüntüsü.
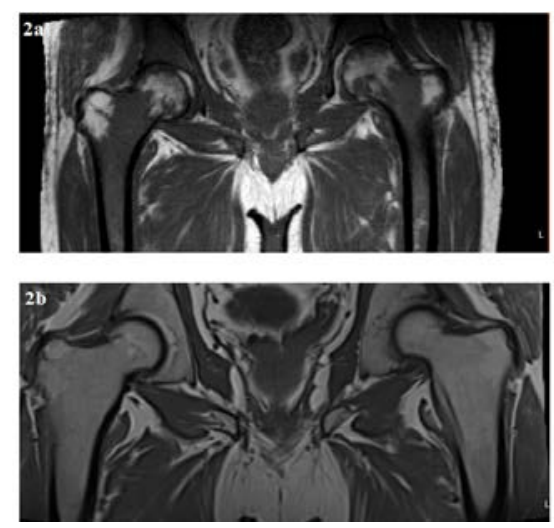

Şekil 2.

a) Hastanın tanı anındaki MR görüntüsü. b) Hasta remisyona girdikten sonraki kontrol MR görüntüsü.

\section{Tartışma}

FBAVN, travmatik veya non-travmatik nedenlere bağlı iskemik kemik nekrozudur. Bilinen nontravmatik nedenler arasında alkolizm, steroidler, kemoterapötik ilaçlar, orak hücreli anemi, talasemi gibi hematolojik hastalıklar, gaucher hastalığı ve gebelik sayılsa da idiopatik olgular mevcuttur ${ }^{4}$. FBAVN riski, lösemilerden özellikle steroidlerin anti-lösemik tedavide uzun süre ve yüksek dozda kullanıldığı ALL olgularında artmaktadır ${ }^{5}$. AML için ise tedavi sürecinde antiemetik amaçlı veya allojenik kök hücre nakli yapılan hastalarda graft versus host hastalığ 1 tedavisine yönelik verilen steroid tedavisi ile risk artmaktadır. Bu grup hastalarda erken tanı için görüntüleme yöntemleri ile rutin tarama konusunda görüş birliği yoktur 6 . Lösemilerde koagülopati nedeniyle FBAVN'ye yönelik cerrahi tedavi seçenekleri kısıtlı olabileceğinden medikal tedavi ön plana çıkmaktadır. Bu yaklaşımlar arasında yatak istirahati ve analjezik tedavinin yanında; patofizyolojisine yönelik olarak farmakolojik tedaviler (bifosfonatlar, ilioprost gibi vazodilatörler, statinler ve koagülopati nedenli kontrendike değilse warfarin, enoksaparin gibi antikoagülan ilaçlar) say1labilir $^{7,8}$. Burada sunduğumuz kemoterapi ve steroid naif AML olgumuzda FBAVN benzeri görünüm, lösemi ile eş zamanlı olarak ortaya çıkmış, hatta hastanın hekime başvurmasını sağlayan neden olmuştur. $\mathrm{Bu}$ olguda FBAVN gelişimine AML'nin katkıda bulunmuş olabileceği veya iki durumun rastlantısal olması durumu da belirsizdir, ancak AML tedavisiyle progresyon göstermemesi AML patogenezi ile bağlantılı olabileceği görüşünü destekleyebilir. FBAVN'de Evre 0 olgular ancak histolojik olarak tanınabilirken evre 1 de MR'da erken sinyal değişiklikleri fark edilir. Ölü trabeküllerde yeni kemik gelişimine sekonder bulguların direktgrafide ortaya çıkması ancak evre 2 de farkedilir. Evre 3'te subkondral fraktür varken evre 4'de kalçada sekonder artrit mevcuttur ${ }^{4}$. Olgumuzda bahsedilen MR değişiklikleri ve mevcut durumunun biyopsi işlemine uygun olmaması nedeniyle histolojik inceleme yapılmamıştır. Ayırıcı tanıda monoartiküler eklem ağrısı ve ateş gibi benzer klinik bulgularla prezente olup tedavisi geciktirildiği takdirde hızla eklem hasarı, sepsis ve mortaliteye yol açabilen septik artrit de bulundurulmalıdır ${ }^{9}$. FBAVN ile septik artritin ay1rımında kullanılabilecek ideal bir test mevcut değil$\operatorname{dir}^{10}$. Eklem sivisı incelemesinde mikrobiyolojik bulgu saptanmaması septik artriti ekarte etmemektedir ${ }^{9}$. Olgunun ateşinin olması AML'ye veya başka bir odağa bağlı enfeksiyon nedeniyle oluşabileceği gibi septik artrit de ihtimal dahilinde olduğu için hızlıca septik artrite yönelik ampirik geniş spektrumlu antibiyoterapi başlanmıştır. 


\section{Sonuç}

FBAVN ve benzeri görünümler AML gibi beklenmeyen hematolojik hastalıklarda, tanı anında bile karş1mıza çıkabilir. İmmunsupresif hastalarda FBAVN fizik muayene ve görüntüleme bulgularının silik olabileceği ve kalça ekleminin septik artritinden ayrımının zor olduğu, bu nedenle antibiyoterapi gerekebileceği unutulmamalıdır ${ }^{3}$. Olgumuzda AML'ye yönelik remisyon-indüksiyon tedavisi dışında FBAVN'na spesifik bir tedavi uygulanmadığı halde klinik ve radyolojik bulguların kaybolması; bu iki patolojinin ilişkiselliği açısından dikkat çekicidir. Tanı ve tedavide gecikme ciddi morbidite ve mortalite sebebi olabileceğinden; klinisyen, FBAVN ve benzeri artropatilere yönelik farkındalık geliştirmeli ve özellikle semptomatik hastalarda gerekli tanısal incelemeleri vakit geçirmeden uygulamaya koymalıdır.

\section{Etik Kurul Bilgisi:}

Olgu sunumu çalışma Etik Kurul onayı gerektirmemektedir.

\section{Kaynaklar}

1- Chang CC1, Greenspan A, Gershwin ME. Osteonecrosis: current perspectives on pathogenesis and treatment. Semin Arthritis Rheum. 1993 Aug;23(1):47-69.
2- Sorich MM, Cherian JJ, McElroy MJ et al. Osteonecrosis of the Hip in Hematologic Disease: A Review of Conditions and Treatment Options. J Long Term Eff Med Implants. 2015;25(4):253-68

3- Tan TJ, Tan SC. Concomitant early avascular necrosis of the femoral head and acute bacterial arthritis by enteric Gramnegative bacilli in four oncologic patients. Singapore Med J. 2013 May;54(5): e108-12.

4- Drescher W, Pufe T, Smeets R et al. Avascular necrosis of the hip- diagnosis and treatment., Z Orthop Unfall. 2011 Apr;149(2):231-40; quiz 241-2. doi: 10.1055/s-0030-1270984. Epub 2011 Apr 5.

5- Arico M, Boccalatte MF, Silvestri D et al. Osteonecrosis: An emerging complication of intensive chemotherapy for childhood acute lymphoblastic leukemia., Haematologica. 2003 Jul;88(7):747-53.

6- Alguacil Pinel, P. Vila Vives, M. Salom Taverner. Avascular necrosis of the femoral head in patients treated for leukaemia. Assessment of the need for a diagnostic protocol. Rev Esp Cir Ortop Traumatol Sep-Oct 2017;61(5):331-338.

7- Mont MA, Carbone JJ, Fairbank AC. Core decompression versus nonoperative management for osteonecrosis of the hip. Clin Orthop Relat Res. 1996

8- https://www.uptodate.com/contents/osteonecrosis-avascularnecrosis-of-bone

9- Niels Christian Kromann, Maria Egede Johansen, Jesper Hvolris. Septic Arthritis. Ugeskr Laeger.2017 Jan 16;179(3): V03160183.

10- P Christopher Cook. Transient Synovitis, Septic Hip, and LeggCalvé-Perthes Disease: An Approach to the Correct Diagnosis. Pediatr Clin North Am. 2014 Dec;61(6):1109-18. 
